\title{
RATIONALE FOR THE LONG-TERM STRATEGY OF THE DESTROYED CHORNOBYL UNIT IV CONVERSION INTO ECOLOGICALLY SAFE SYSTEM
}

\author{
Yu.Kostenko, K.Rudya \\ Ministry for Environmental Protection and Nuclear Safety of Ukraine
}

Received December 10, 1997

\begin{abstract}
Overview of the factors affecting long-term strategy decisions on the conversion of the ruined unit 4 of the Chornobyl nuclear power plant is given. The essence of the strategy is a complete and final removal of the hazards peculiar to the "Shelter". The total amount of fuel residuals in the "Shelter" comes to 200 tons of uranium dioxide. The fuel masses physical and chemical state is subject to increasing change with time, thus leading to the negative modification of their nuclear physical characteristics. Cooling down, cracking and erosion of the vitrified fuelcontaining masses increase their water penetrability and lead to the gradual growth of the system reactivity. Instability of the damaged unit 4 structures, as well as of the "Shelter" itself creates the hazard of local and major collapses. In these conditions the probability of the criticality cannot be excluded. Moreover, real events that took place in 1990 and 1996 demonstrated a very uncertain situation with safety parameter monitoring and control. The listed factors provide a solid basis for the strategy of fuel removal, isolation and disposal in accordance with international and national regulatory requirements, a process to be started as early as possibly, after preliminary stabilization of the existent structures and parallel implementation of the local isolation and localization measures, preparation of the relevant waste management infrastructure, etc.
\end{abstract}

\section{Introduction}

Any option for achieving the "Shelter" long-term safety implies a great resource and intellectual expenditures. Incorrect action strategy may lead to the waste of resources and efforts without removing the actual hazard.

In view of that, the rational basis of the long-term strategy for the conversion of unit IV of the Chornobyl NPP into the environmentally safe system would be a removal of all essential hazards associated with the Shelter. Therefore, the analysis of the relevant hazards is the first step to establishing priority of the relevant strategic targets and tasks. In making this analysis we should adequately 
take into account the extent of uncertainties associated with the parameters important to the safety, time factor of the hazard, as well as conservative approaches to the evaluation of nuclear and radiation safety.

\section{General characteristic of the fuel masses of the "Shelter"}

The main source of hazard within the "Shelter" is a significant amount of nuclear and highly radioactive materials. According to the latest estimates the total amount of the fuel residuals in the "Shelter" comes to 200 tons of uranium dioxide. There were 1659 fuel assemblies in the reactor core at the moment of the explosion. It is assumed that about $95 \%$ of this amount, that is 179 tons of fuel masses have remained within the "Shelter" boundaries. One should also add approximately 20 tons of utilized and fresh fuel that had been available in the reactor hall and its cooling ponds.

Melted fuel masses mainly concentrated in a "fuel lake" in room 305/2 under the reactor, and partially spread further horizontally through the mechanical or thermal breakthrough in a $1.5 \mathrm{~m}$ concrete wall into the lateral room $304 / 3$, and vertically - to lower elevations of the unit including the pressure suppression pool.

According to moderate estimates, in the under-reactor compartments of unit 4 there are more than 120 tons of fuel masses and a major portion, from 50 to 110 tons (the mean figure 75 tons) being concentrated within compartment 305/2. In room 304/3, where neutron detectors of the monitoring system "FINISH" are installed, there are only 10-14 tons of the fuel masses. It means that detection of neutron anomalies by those sensors can be caused either by measuring mistakes or some powerful events, primarily in the neighbouring compartment 305/2. Data differences are stipulated by the complex structure and non-uniformity of the fuel masses, their geometry and limited access. A number of fuel-containing compartments were filled with concrete during the construction stage, thus complicating significantly the fuel masses inventory and characteristic of their condition.

\section{Potential physical phenomena and real precursors}

Conclusions on the potential hazardous status of the "Shelter" are primarily based on the quantitative assessments of the fuel amount within the Shelter and the rate and nature of the transformation of their properties. The physical and chemical state of the fuel masses is increasingly changing with time, thus leading to the negative modification of their nuclear physical characteristics. Cooling down, cracking and erosion of the vitrified fuel-containing masses increases their water penetrability and leads to the gradual growth of the system reactivity. The amount of water inside the "Shelter" is increasing because of rain and snow water income and accumulation of condensed moisture. Leaching of neutron absorbing elements also contributes to the reactivity growth. 
In addition, instability of the damaged unit 4 structures, as well as of the "Shelter" itself constructed in harsh conditions within limited time, creates the hazard of collapses which can lead to the criticality occurrence, as a result of the substantial change in the fuel masses and graphite blocks layout, rate and character of the water intake and uptake by cracked and cooled fuel masses. The calculated minimal critical parameters for the homogenous water/uranium dioxide ( $2 \%$ enrichment) mixture are $404 \mathrm{~kg}$ and $51 \mathrm{~cm}$ (diameter of the sphere).

There is negligible likelihood of the 1986-like scenario of prompt criticality with the explosion mechanism and global consequences, though a realistic "calm" scenario of reaching sustainable criticality (self-sustainable chain fission reaction) is not unlike at all. Feasibility and sustainability of this scenario is illustrated by a well-known example of the natural reactor in Oklo, Southern Africa, which had been functioning by itself for hundreds of years. Potential hazard of the "calm" sustainable criticality consists in the generation of new nuclides, such as iodine, cesium, strontium, etc., resulting in the deterioration of the dose-rate and airborne activity in the Shelter and at least on the Chornobyl site, thus affecting any activity in the "Shelter" and on the site.

On 12 September 1996, two neutron sensors of the monitoring system "FINISH" (No.7 and No.8) installed in compartment 304/3 registered growth of the neutron flux density with overshooting of the control and emergency levels (No. 7 - from 95 to $316 \mathrm{n} / \mathrm{cm}^{2} \mathrm{~s}$, No.8 - from 85 to $317 \mathrm{n} / \mathrm{cm}^{2} \mathrm{~s}$ ). Simultaneously, doubled dose-rate readings were registered by the dose-rate sensor installed in the reactor vault, approximately above the compartments where neutron anomaly was registered.

A simultaneous neutron flux density growth was registered by all the three channels of the independent criticality alarm system (ICAS), with neutron detectors installed in compartment $305 / 2^{(1)}$.

Similar series of neutron anomalies, followed by alarm signals, were registered by the both monitoring systems also on September 16, and a short-term (1 minute) excursion - on September 19. The time and spatial correlation between the readings of the two independent systems was identified. The simultaneous measuring of the airborne activity within the "Shelter" detected neither change nor releases or additional contamination on the premises.

Visual inspection of the accessible under-reactor compartments did not reveal any visible anomaly which could be regarded as a consequence or a precursor of the criticality.

Similar phenomena were observed in January and April 1987, June 1990 and January 1996. In 1990 sensor No. 7 in compartment 304/3 registered nearly

\footnotetext{
${ }^{1)}$ FINISH - main operational monitoring system having 55 measuring channels: 8 dose-rate, 8 - neutron flux density, 11 - thermal flux, 28 - temperature measurement. Commissioned in 1988-1989.
}

ICAS - criticality alarm system having 16 measuring channels. It is fully independent of FINISH in measuring channels and power supply, and now is being tested. 
60 excursions of neutron flux, until the neutron flux growth was suppressed by sprinkling of the neutron poison solution (gadolinium nitrooxide) in the compartment. Investigation of this incident took more than one year. The ensuing expert conclusion states that the phenomenon could have been caused by criticality occurrence in compartment $305 / 2$, though this fact requires additional confirmation within a much more profound study of the nuclear safety of the "Shelter". It is known that the probability of measuring mistakes was completely excluded.

Analysis of the neutron anomalies, the available experimental and analytical criticality studies give evidence of the current subcriticality of the fuel masses. At the same time, analytical studies of some scenarios indicate a potential for criticality occurrences. Though the technical status, effectiveness and accuracy of the available monitoring systems do not allow us either to identify exactly the registered events as criticality occurrences, or to exclude this option with a sufficient certainty. Detailed clarification of the circumstances and causes of the described neutron anomalies requires further studies of the quantity, distribution and nuclear characteristics of the essential fuel bulks within the "Shelter".

\section{Recommendations and conclusions}

The considered above issues strongly testify to the fact that the final goal and essence of the "Shelter"'s conversion into the environmentally safe state is removal, isolation and safe disposal of the fuel residuals in accordance with reasonably strict regulations. In view of the growing intensity of the processes of physical and chemical degradation (leaching and erosion, etc.), it becomes clear that this operation should be started as soon as possible, after the completion of a relevant stabilization of the "Shelter", the development of effective fuel removal technologies and approaches, preparation of the nuclear and radioactive waste management infrastructure, etc.

It is reasonable to split the whole conversion process into two sequential stages - urgent measures and intermediate/long-term ones.

The urgent measures include immediate improvement of the organization and the technical status of the neutron and dose-rate monitoring systems, that implies furnishing with additional equipment for neutron and dose-rate monitoring, airborne activity, etc., as well as introduction of a special Technical Specification for measuring nuclear and radiation parameters and emergency response. In addition, to increase subcriticality margin in case of the system reactivity excursion (chemical degradation of fuel residuals, collapse of the structures leading to a substantial change in fuel/moderator geometry, etc.), it is reasonable to install neutron poisons in the most concentrated location of fuel residuals.

Intermediate and long-term stages involve development and implementation of a set of strategic measures to ensure long-term nuclear and radiation safety of 
the "Shelter", aimed at the removal of the most hazardous bulks of fission and highly radioactive materials and their safe disposal in compliance with the relevant national and international regulations. They include:

- prevention of the fuel masses layout configuration change (local and general stabilization of the "Shelter" civil structures);

- installing stationary safety systems for dust suppression, fire fighting, neutron poisons in case of a criticality incident, ;

- preparation for the fuel removal, isolation and disposal;

- profound analysis of the calculations concerning studies on the criticality occurence probability in different zones of the 'Shelter'; additional characterization of the fuel amount, its distribution and physical parameters.

Erection of a protective containment (Shelter-2) will not solve major safety problems of the ruined unit 4 :

Firstly, construction of a complex engineering containment in practice would indefinitely delay the fuel removal start, taking into account the efforts, costs and time needed for the implementation of this project.

Secondly, construction of the containment itself would require preliminary stabilization of the existent "Shelter" and civil engineering preparations. It should be noted that stabilization itself is the most effective measure preventing ensuing radioactive releases excluding accidental collapses of the unit 4 structures. At the same time, judging by the results of Alliance concern study, even a heavy engineering containment has little chance to withstand relevant initiating events, such as earthquakes of magnitude 6 , tornados, etc., or a spontaneous collapse of the old "Shelter".

That is why the essential elements of the rational strategy for the ruined unit 4 conversion into environmentally safe condition should foresee the fuel removal with preliminary stabilization of the existent structures and parallel implementation of the local isolation and localization measures.

\title{
ЕЛЕМЕНТИ ДОВГОСТРОКОВӦ̈ СТРАТЕГіЇ ЩОДО ПЕРЕТВОРЕННЯ ЗРУЙНОВАНОГО 4-ГО БЛОКУ ЧАЕС В ЕКОЛОГІЧНО БЕЗПЕЧНУ СИСТЕМУ
}

\author{
Ю.Костенко, К.Рудя
}

\footnotetext{
Подається огляд фракторів, що мають вплив на довгострокову стратегію з перетворення зруйнованого 4-го енергоблоку Чорнобильської АЕС. Сутністю стратегії є повне й остаточне вилучення небезпеки, яку криє в собі об'єкт "Укриття" (ОУ). Загальна
} 
кількість диоксиду урану всередині ОУ складає біля 200 тон. Фізичний та хімічний стан ядерних мас змінюється з часом, що веде до негативних змін їх ядерно-фізичних характеристик. Охолодження, розтріскування та ерозія паливомісних мас збільшують проникнення води й ведуть до зростання реакційної здатності системи. Нестабільність структур зруйнованого 4-го блоку та самого ОУ створюють небезпеку локальних та загальних руйнацій. У таких умовах можливість критичного стану не може виключатись. Більше того, справжні події, що мали місце 1990 та 1996 року, продемонстрували дуже ненадійну ситуацію 3 моніторингом і контролем параметрів безпеки. Перелічені фактори забезпечують тверду основу для стратегії вилучення палива, ізоляцію та захоронення відповідно до вимог міжнародного та національного регулювання. Це процес, що повинен розпочатися негайно, після попередньої стабілізації існуючих та паралельних структур із заходів 3 ізоляції та локалізації, приготування відповідної інфраструктури 3 обробки відходів, тощо. 